\title{
Image and Signification of the Neo-Moorish Architecture in Algeria Case Study: The Big Post Office in Algiers
}

\author{
Amina Chalabi ${ }^{1, *}$, Youcef Lazri ${ }^{2}$ \\ ${ }^{1}$ Department of Architecture, Faculty of Architecture and Urbanism, University Salah Boubnider Constantine 3, Algeria \\ ${ }^{2}$ Department of Architecture, Faculty of Science and Technology, University May 8, 1945 Guelma, Algeria
}

Received March 7, 2021; Revised May 20, 2021; Accepted June 6, 2021

\section{Cite This Paper in the following Citation Styles}

(a): [1] Amina Chalabi, Youcef Lazri, "Image and Signification of the Neo-Moorish Architecture in Algeria Case Study: The Big Post Office in Algiers," Civil Engineering and Architecture, Vol. 9, No. 4, pp. 1246-1256, 2021. DOI: 10.13189/cea.2021.090426.

(b): Amina Chalabi, Youcef Lazri (2021). Image and Signification of the Neo-Moorish Architecture in Algeria Case Study: The Big Post Office in Algiers. Civil Engineering and Architecture, 9(4), 1246-1256. DOI: 10.13189/cea.2021.090426.

Copyright $(2021$ by authors, all rights reserved. Authors agree that this article remains permanently open access under the terms of the Creative Commons Attribution License 4.0 International License

\begin{abstract}
Algeria is one of the Maghreb countries that lived through French colonialism, a colonialism that left behind a great architectural and urban legacy that adorns Algerian cities and is an integral part of their urban landscape. This legacy consists of a mosaic of architectural styles ranging from neo-classical to buildings of the modern movement through art Deco and neo-Moorish style. The specificity of the neo-Moorish architecture, which is based on its cultural references inspired by the local architecture, has given it a special place among the inhabitants. The public buildings of the neo-Moorish style have become today's important landmarks in Algerian cities. As any form of architecture has a meaning for the users, we tried in the present work, to verify empirically the question of the social representation of the neo-Moorish style in Algeria and the relationship that a local population can maintain with an architectural heritage issued from the colonial period. This is done through a symbolic example, which is the great post office in Algiers. We opted for a qualitative approach carried out in the field with the help of a methodological tool, a questionnaire-based survey. A survey, which, despite these limits in terms of the inhabitant's predisposition and the disparity of points of view between the generations, revealed a collective acceptance and an attribution of multiple heritage values to this legacy. Finally, this will allow us to inscribe this social representation in the logics of institutional heritage.
\end{abstract}

Keywords Architectural Language, Neo-Moorish, Architectural and Decorative Elements, Social Representation- Algeria

\section{Introduction}

In Algeria, "The classical architecture of European affiliation was for seventy years the official architecture of the French empire in Algeria"[1]. The turn of the twentieth century marked the beginning of a period rich in artistic creation similar to what was happening in Europe at the same time.

The period from 1900 to 1930 witnessed, "a humanistic approach, an attempt to recover and reinterpret the values of the traditional architecture and urban heritage in modern buildings, in short, a strong desire to arabize the built environment"[2]. This infatuation with the reinterpretation of traditional models gave birth to the neo-Moorish architecture. A style that fits both in the Orientalist movement (A movement that marked the early twentieth century), and also in the trend of architectural eclecticism that has known the occidental architecture from the nineteenth century based on the renewal of different architectural styles in the form of architecture called "neo" as neo baroque, neoclassical, etc.... 
According to François Béguin [3] it is a protective style, invented to divert the attention of the colonized inhabitants and to remedy the uneasiness felt in front of the neo-classical style ("style of the victor") which invaded the landscape of the Algerian cities since the beginning of the colonization.

It is a protective style, invented to remedy the uneasiness felt by the colonized inhabitants who saw the neo-classical style ("style of the victor") invading the landscape of their cities". It is a picturesque style distinguished by its ornamentation based on many borrowings from Andalusian-Maghrebian architecture. The architecture of urban centers in Algeria, whether on an architectural or urban scale, was influenced by the Arab-Muslim civilization [4].

At the beginning of the 20th century, many buildings were built in this style and gradually changed the face of Algerian cities. Among these architectural jewels we can cite:

- The medersa [5] of Tlemcen [Figure 1, a], (in the West of Algeria), signed by the architect Henri Petit and inaugurated on May 6, 1905. It was the second building designed by the same architect in the neo-Moorish style after the medersa of Algiers, with a magnificent façade inspired by the mihrab [6] of the great mosque of Tlemcen.

- The railway station of Oran [Figure $1, b]$, in the west of Algeria, is one of the most sumptuous buildings of Oran, part of the large repertoire of the architectural legacy from the French colonization in Algeria, signed by the architect Albert Ballu, inaugurated in 1913. It was entrusted to the company of the Perret brothers. For the French railway company PLM.

- The medersa of Constantine [Figure 1, c], in the East of Algeria, was built between 1906-1909 by the architect Pierre-Louis Bonnel. Its drawings were established by the architect Albert Ballu (1849-1939) occupying at the time the post of inspector general of the architectural service of Algeria. It was inaugurated on April 24, 1909. After several conversions, the building now serves as a "center dedicated to the historical and cultural figures of the city of Constantine".

- The town hall of Skikda [Figure 1, d], in the east of Algeria, emblematic building and architectural jewel of neo-Moorish style, was built in front of the port. It was inaugurated in 1931 and signed by the talented architect Charles Montaland. Its luxurious architecture makes it a small palace combining tradition and modernity.
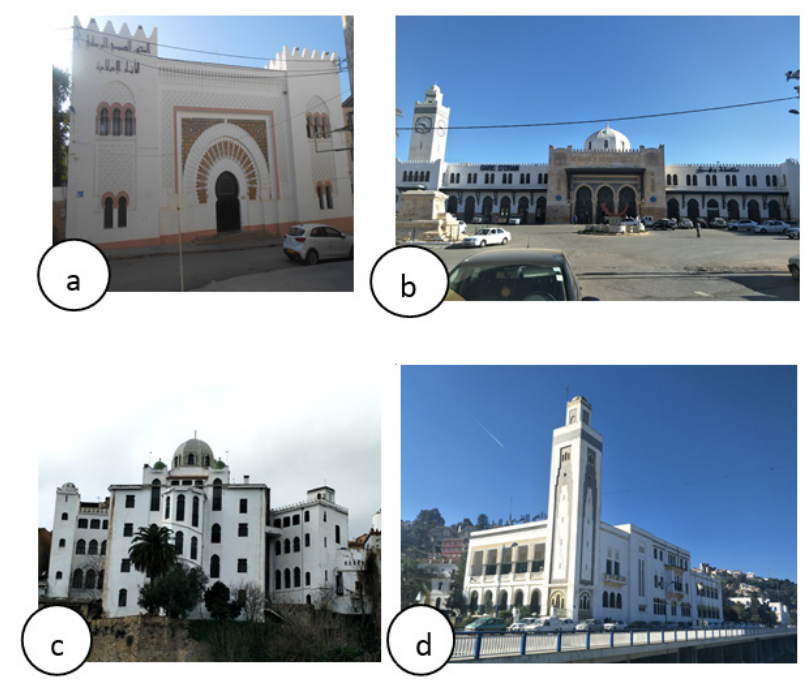

Figure 1. Examples of public buildings, neo-Moorish style in different Algerian cities (Photos Authors, 2019)

Algiers, in particular, was embellished with public buildings that gave the city a specific character and an image of "a thousand and one nights" promoting tourist activity due to the mythical oriental landscapes. Among these buildings, we can mention:

- The medersa of Algiers (presently the National Office of Education and Distance Learning)was the first neo-Moorish building in Algeria. This building is the work of the architect Henri Petit and was inaugurated in 1904, intended for the higher education of young natives.

The big dome and the halls present a very harmonious architectural framework. It is now occupied by the National Office of Education and Distance Learning [Figure 2].

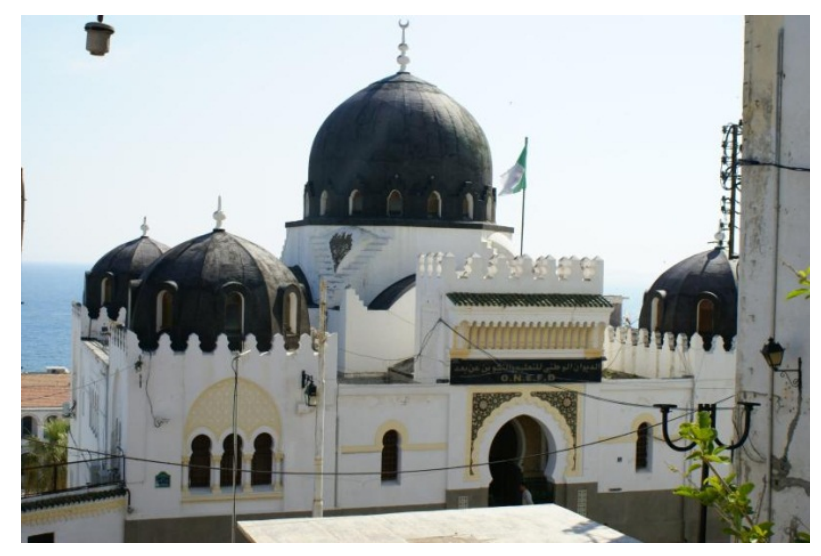

Figure 2. Example of the medersa of Algiers, inaugurated in 1904, architect: Henri Petit (https://casbah-alger.com/) 
- The hotel of Prefecture (presently headquarters of the wilaya of Algiers)

The prefecture of Algiers, designed by the architects Jules Voinot and Darbéda, was built between 1906 and 1913. The building is equipped with three domes on its roof. Its facade is made up of superimposed loggias inserted in horseshoe arches resting on marble columns [Figure 3, (4)].

\section{- The headquarters of the Algerian Dispatch (presently headquarters of the National Democratic Rally)}

This building, located a few meters from the big post office of Algiers, was built between 1906 and 1913, signed by the architect Henri Petit. A Maghrebian minaret and a spacious gallery with horseshoe arches and twin columns mark its facade. Its architecture combines the characteristic elements of the Moorish house and those of the mosque in a French reinterpretation [Figure 3, (2)].

\section{- The Galleries of France (presently public Museum of modern and contemporary art of Algiers)}

The Galleries of France inaugurated in 1909, an emblematic building of neo-Moorish style conceived by the architect Henri Petit, was located in the city center of Algiers, in an urban site of great patrimonial interest. It is endowed with a minaret at its corner, and presents facades with large bays with horseshoe arches and a luxurious ceramic decoration. All of this gives the building an exceptional character, which today makes it one of the city's landmark buildings.

After the independence in 1962, the galleries of France became "Algerian Galleries". In 2007, the building will be reconverted in National Museum of Modern and Contemporary Art of Algiers, and classified as a historical monument [Figure 3, (3)].

- At the end, we cite the big post office of Algiers, which constituted an architectural jewel [Figure 3, (1)].

Towards the 1930s, with the celebration of the centenary of the French colonization of Algeria, this trend begins to fade, giving way to a more modern style stripped of all ornamentation. The transition "From an architectural style for the pacified colony, namely the neo-Moorish style... to finally arrive in the city of the 1930s"[7], [2] was mainly attributed to the advent of the modern movement that invaded the world at that time.

Today, the buildings that reflect the aesthetic, artistic and architectural richness of the neo-Moorish style are numerous; they are important parts of the urban landscape of Algerian cities and are considered as identity and tourist landmarks, which conceal intrinsic and extrinsic plural values.
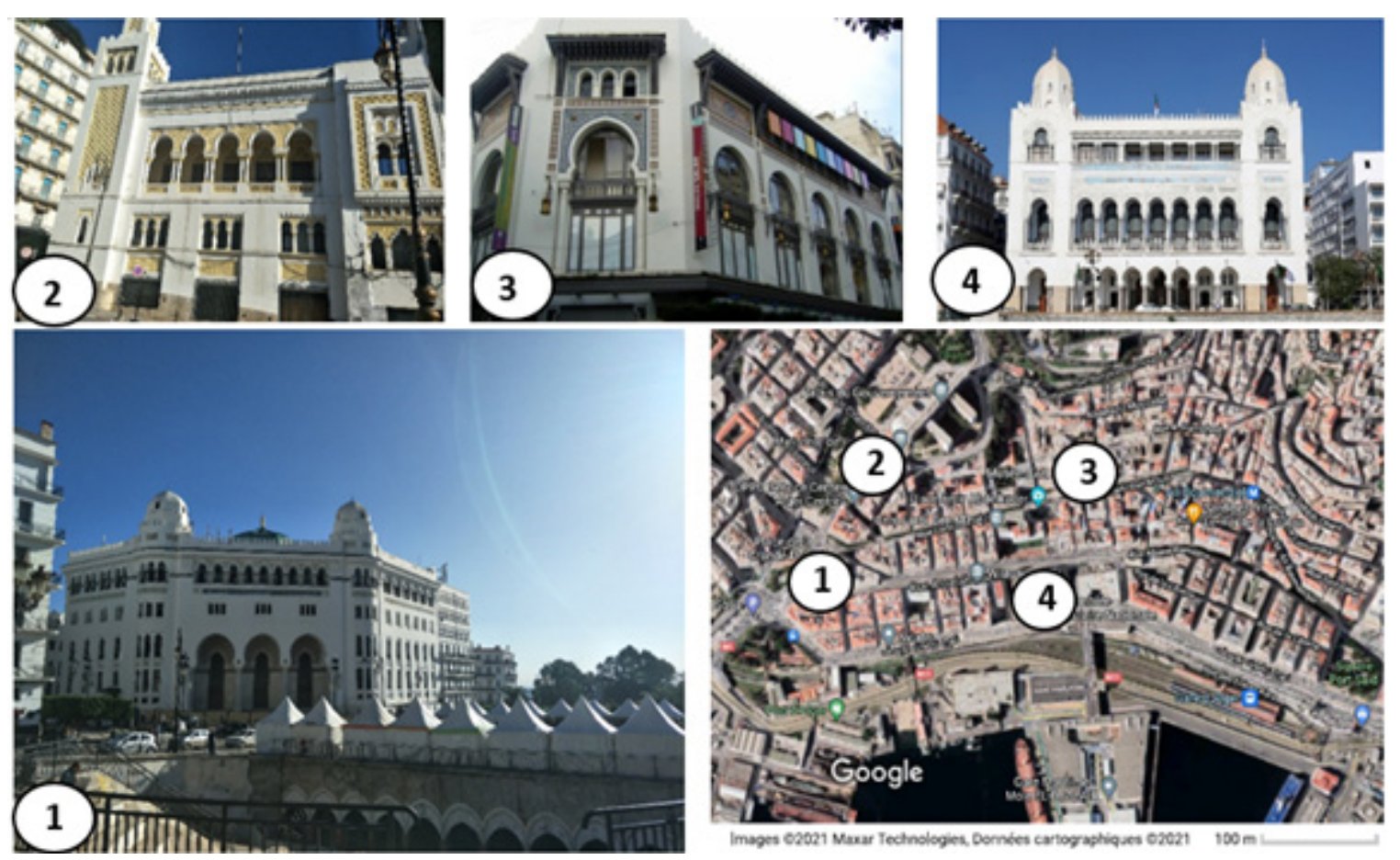

Figure 3. Locations of neo-Moorish buildings in Algiers (Source; Photos (1, 2): Authors, 2019, Photo (3): https://www.tripadvisor.fr/ Photo (4): https://www.inter-lignes.com/la-wilaya-dalger-autorise-la-reprise-de-certaines-activites-professionnelles/, 
The protection and the conservation of a heritage objects as well as its patrimonialization requires the crossing of several orders of realities. The first one is institutional, legal, regulatory and administrative, and the second one is linked to the meaning that the society attaches to the heritage objects in terms of identity, temporal and aesthetic references $[7,8]$. It is a question of going beyond institutional logics in terms of heritage and shedding light on the perception of the current populations [9]. We try in the present work, through the example of the big post office in Algiers, to study the social representation of an architecture dating from the colonial period, but charged with local cultural references. We are essentially interested in the image and signification that it awakens in the inhabitants. We will try to answer the question of the relationship that a local population can maintain with an architectural heritage from the period of French colonization.

The main objective of this study is to test the degree of attachment and knowledge of the society on the neo-Moorish architectural production, which will allow a better heritage recognition.

\section{Literature Review}

\subsection{The Social Representations of Architecture; Between Image and Signification:}

The social representation of an architectural product can be defined as "an organized set of opinions, attitudes, beliefs and information referring to an object or situation"[10]. It represents "The innocent, everyday reading of the quidam, made up of feelings, impressions, and reactions to various stimuli (noise, light, color, material, scale, rhythm, architectural style, beauty/glamour, memories and references)"[11,12].

Any process of patrimonialization is the result of social representation. Beyond the intrinsic values that a patrimonial object may have, its judgment and appreciation is above all linked to the different values that the community assigns it [13].

In the present work, we are interested in the ordinary relationship of the populations to the public buildings of the neo-Moorish style; the expert relationship has been voluntarily omitted.

Several works have dealt with this social representation. We cite them as an example: the work of Navez-Bouchanine Françoise on "The ordinary inhabitants of the medinas in Morocco" [14], those of Vergès Pierre on "The analysis of social representations by means of questionnaires" [15], as well as the work of Cyril Isnart on "Ordinary patrimonializations" [16].

\subsection{The Specificity of Neo-Moorish Architecture}

Despite its belonging to the colonial architectural legacy, the neo-Moorish architecture is accepted by the population, it is even appreciated. Today, it has a great importance in the collective memory of Algerians, who have an emotional attachment to its neo-Moorish buildings decorated with local references that have become landmarks of Algerian cities.

It conceals undeniable artistic and aesthetic values, particularly in terms of decorative elements inspired by local architecture. The constructive techniques and the decorative arsenal that it includes present an important know-how that deserves to be studied, as well as offers the students a relevant example of the modes of reinterpretation of local architectures.

\subsection{The Big Post office of Algiers Symbol of the Neo-Moorish Style in Algeria}

It is located in the center of Algiers (capital of Algeria) [Figure 4], standing out as a major tourist attraction and a favorite meeting point for the people of Algiers.

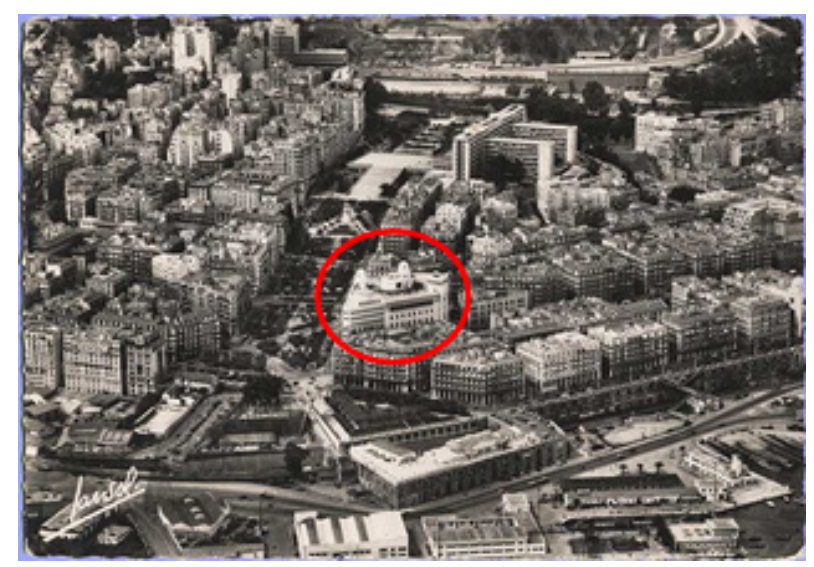

Figure 4. Aerial view - Downtown Algiers. Editions Jansol, postcards, exceptional series

The symmetry of the classical European tradition is combined with the attributes of the Orient [Figure 5]. Built under the order of the governor general Charles Celestin Jonnart (Governor General of Algeria 1900-1911), it was conceived by the architects Jules Voinot, architect formed in Algiers and Denis Marius Toudoire, architect, formed in the school of Arts of Paris, realized in collaboration with local artists. It was started in 1910, and inaugurated in 1913. Initially destined for the PTT (Post, Telegraph and Telephone), a powerful public service institution during the colonial period.

In spite of its 106 years, the big post office is still beautiful and majestic. It housed the greatest post office of independent Algeria until 2014, when the project of its conversion into a museum of the history of the post and telecommunications of Algeria was launched in order to give new life to this architectural jewel. The former Minister of Postal Services and Information and Communication Technologies, Zohra Derdouri launched the project in July 2014. 


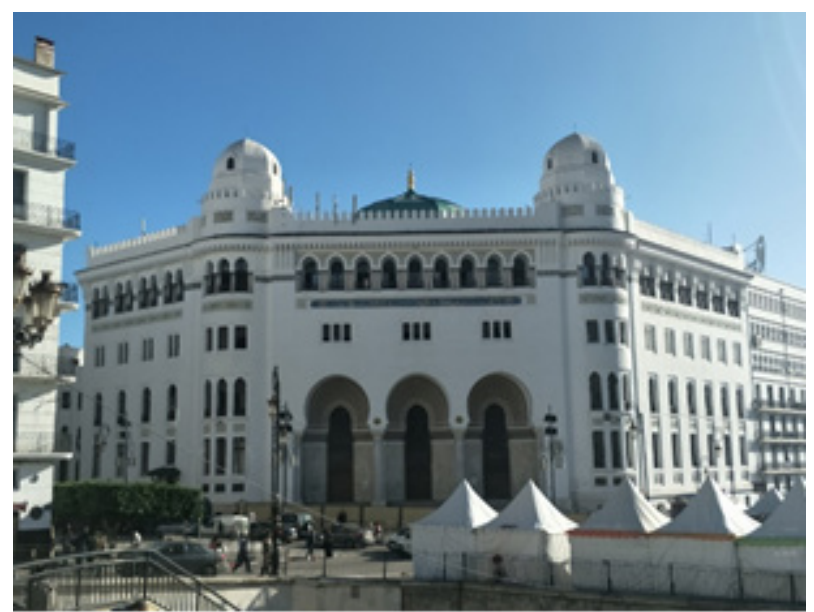

Figure 5. The big post office in Algiers (Voinot and Tondoire 1909-1913) (Photo Authors, Nov.2019)

\section{Methods}

In order to conduct a reading of the image and signification of neo-Moorish architecture among the inhabitants of Algerian cities, we opted for an empirical study, following a qualitative approach of an exploratory nature.

We are interested in the relation of signs to meanings and signification [17]. "It is a question of analyzing the relationship of forms to the meaning with which they are charged (personal and subjective meanings) and to the processes of significations that produce this meaning" [18]. This study will allow us to identify the significant elements of this architectural creation and to decrypt the image it awakens in users.

\subsection{Methodology for the Conduct of the Investigation}

\subsubsection{Description and purpose of the interview}

Our approach is an aesthetic approach of the neo-Moorish architecture, which aims to decrypt the point of view of the receiver, a semantic reading that wants to be an attempt at decoding the signs transmitted by this architecture. This is why it will be carried out in the field with the help of a methodological tool, which is based on a questionnaire.

\subsubsection{The objectives of the survey:}

- To understand the reading of a layperson of this architectural production.

- To understand the values transmitted by this heritage.

- To understand the effect of this architecture and decipher the images and meanings, it awakens in the citizens.

\subsubsection{Sample identification}

In view of the empirical techniques that we approached and to construct a representative sample, we referred to the studies by A. Griffin and J. Hauser [19], which stipulate that in a qualitative study, a sample composed of 12 to 30 respondents can offer $70 \%$ of the information to be collected. We thus solicited a representative sample composed of fifty people living in the city of Algiers, a diversified choice of respondents was carried out according to several factors: age, sex, and level of education.

\subsubsection{Questionnaire Organization}

The questionnaire we asked the participants to fill out consists of six axes [Figure 6]:

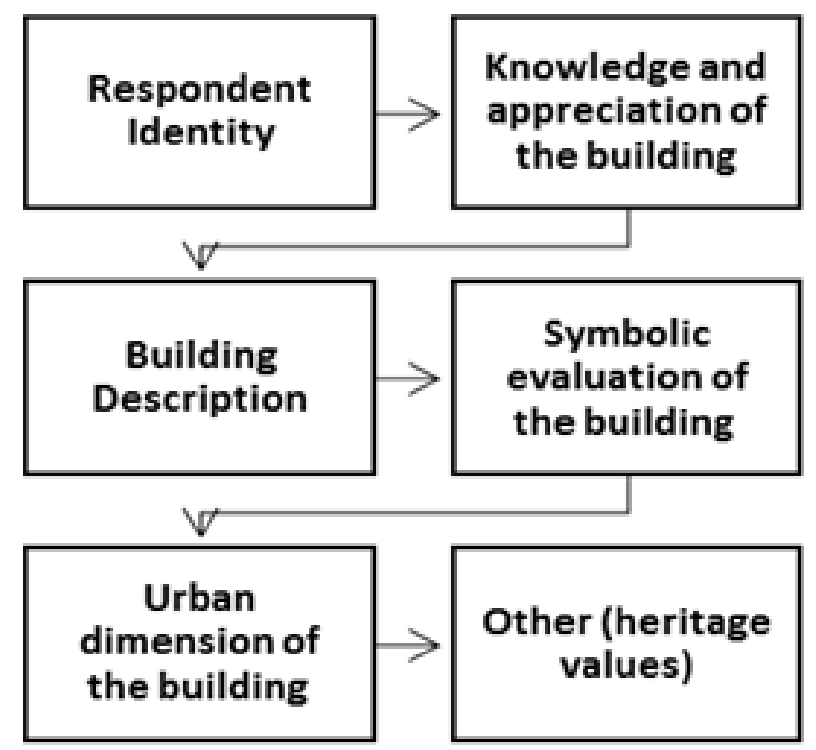

Figure 6. The different axes of the questionnaire presented to the respondents (Source: Authors)

The first axis: is a series of questions designed to develop a profile of the respondent; its variables areage, gender, and level of education.

The second axis: concerns the appreciation of the building by the respondents as well as the degree of their knowledge on the period of its construction and its architectural style.

The third axis: in which we solicit from the respondent a description of the architecture of the building; the description of its shape, the symbolism of its colors, the reading of its facade as well as the description of its architectural and decorative elements.

The fourth axis: in which we try to draw up a symbolic evaluation of the building by questioning the respondents on the meaning and symbolism of the building for them as well as the memory value it can awaken in them.

The fifth axis: concerns the urban dimension of the building; the degree of its importance according to the respondents and the role it can play in the urban space.

The sixth axis: in which we try to establish a heritage evaluation of the building through two questions; the 
question of identification in the architectural style of the building and the question of its patrimonialization.

\section{Results}

\subsection{Identity of Respondents}

Our sample presents a close distribution between the male and female genders of the respondents, with 55\% men and $45 \%$ women [Figure 7], half of which is composed of young people between 25 and 40 years old, with a close distribution between juniors under 25 years old and juniors over 40 years old [Figure 8]. For the level of education, the respondents have a high level of education, with $55 \%$ being university graduates [Figure 9].

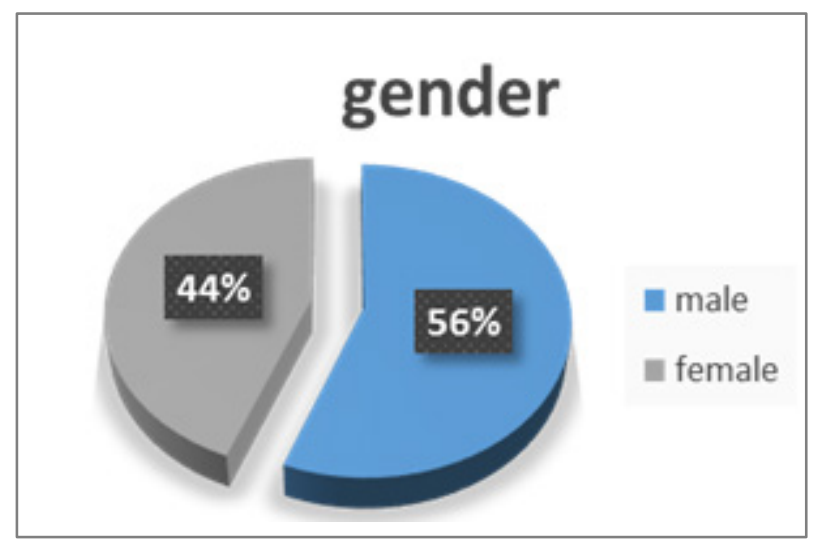

Figure 7. Diagram representing the gender of respondents (Source: Authors)

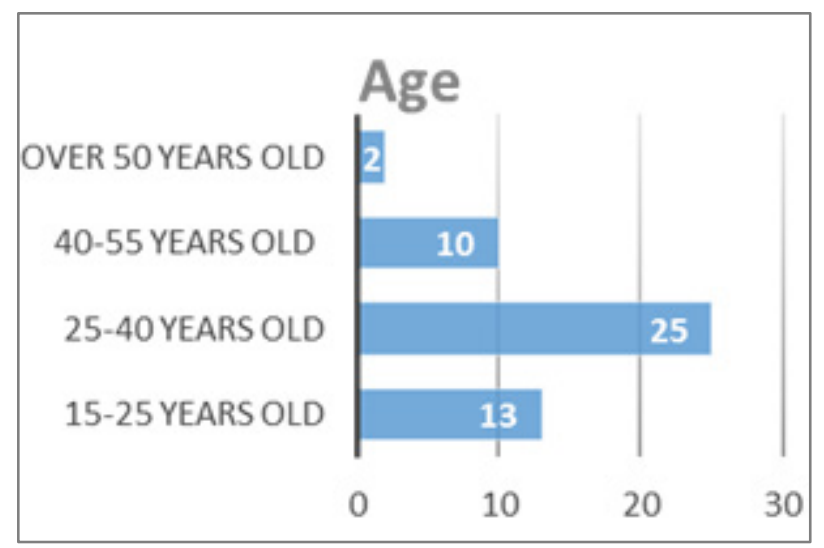

Figure 8. Diagram representing the age of respondents (Source: Authors)

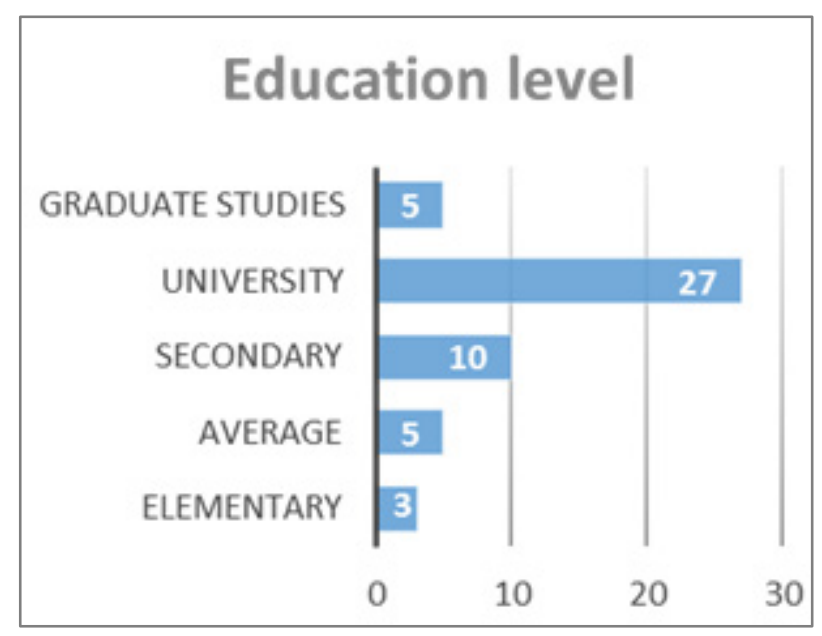

Figure 9. Diagram representing the level of education of respondents (Source: Authors)

\subsection{Knowledge and Appreciation of the Building}

In terms of appreciation of the building, $76 \%$ of respondents appreciated the post office, justifying this positive choice by its aesthetic and architectural value as well as its originality. $24 \%$ of the respondents who did not like the post office justified their opinion by the state of deterioration of the building, its grandiose dimensions and the memory of colonization that it awakens in them [Figure 10].

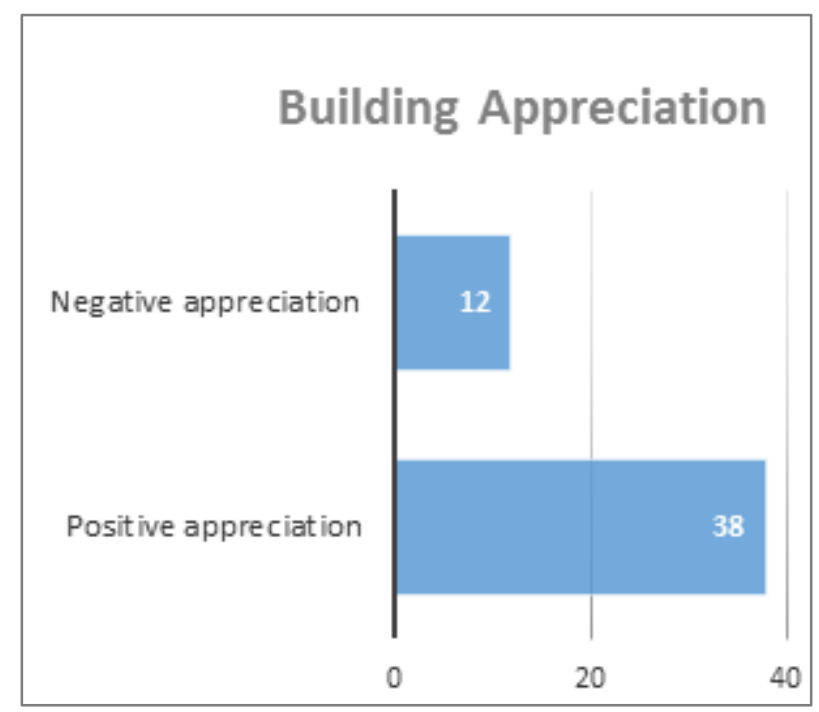

Figure 10. Diagram representing the appreciation of the big post office by the respondents (Source: Authors) 
We note that half of the respondents have some knowledge about the period of the construction of the building. 54\% relating it to the period of French colonization, $30 \%$ of the respondents think that the big post office was built during the period of Turkish occupation and $16 \%$ do not express an opinion on this subject [Figure 11].

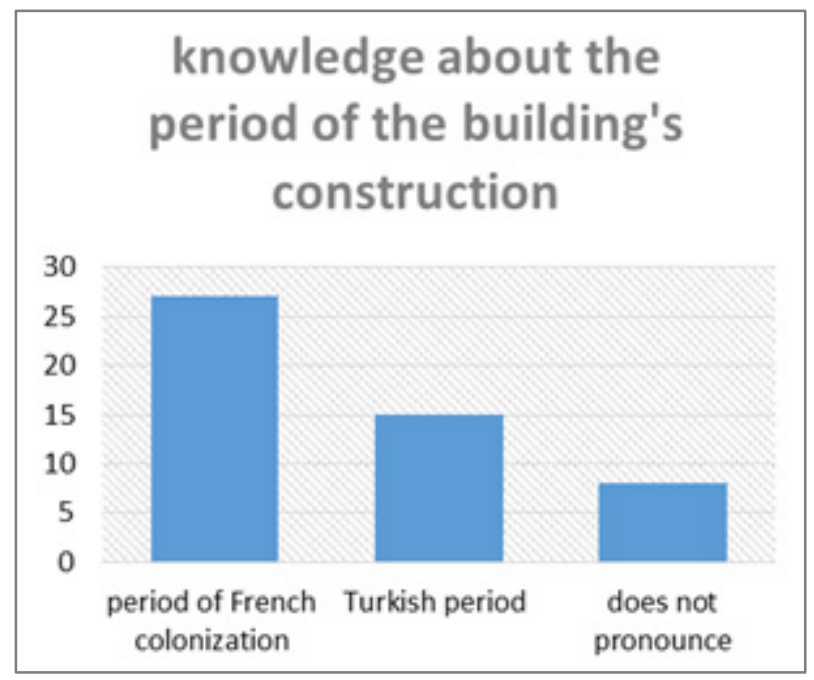

Figure 11. Diagram representing the degree of knowledge of the respondents on the building (Source: Authors)

For the architectural style of the building, the respondents gave four propositions: the Ottoman style with $40 \%$, the Islamic style with $20 \%$, the French style with $10 \%, 6 \%$ of the respondents find that the architectural style of the big post office is a mixture between the Islamic and occidental style [Figure 12].

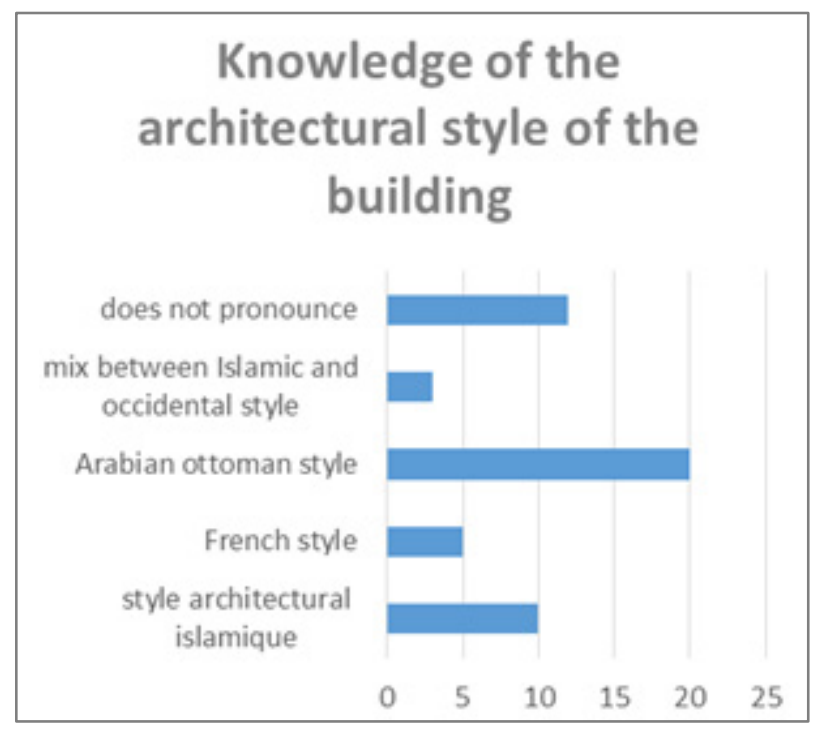

Figure 12. Diagram representing the degree of knowledge of the respondents on the architectural style of the Grande Poste (Source: Authors)

\subsection{Description of the Building}

In order to answer the question of the relationship between the form and the function of the post office, the majority of respondents, $(62 \%)$, considered that its form and its external appearance corresponded much more to a mosque than a post office, while $38 \%$ of respondents did not express an opinion on this issue [Figure 13].

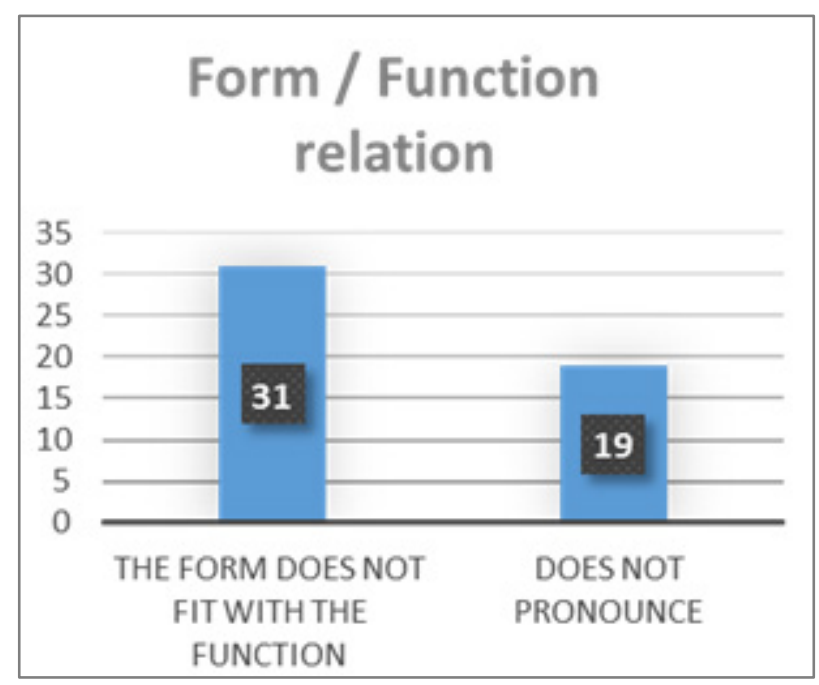

Figure 13. Diagram representing the form/function ratio of the large post office among respondents (Source: Authors)

The symbolism of the white color of the big post office oscillates between peace $(40 \%)$, purity $(16 \%)$, which reflects the image of the city "Algiers the White" (30\%). $16 \%$ of the respondents, considering the degradation state of the building, did not appreciate this color; they found that it was terribly lacking in color [Figure 14].

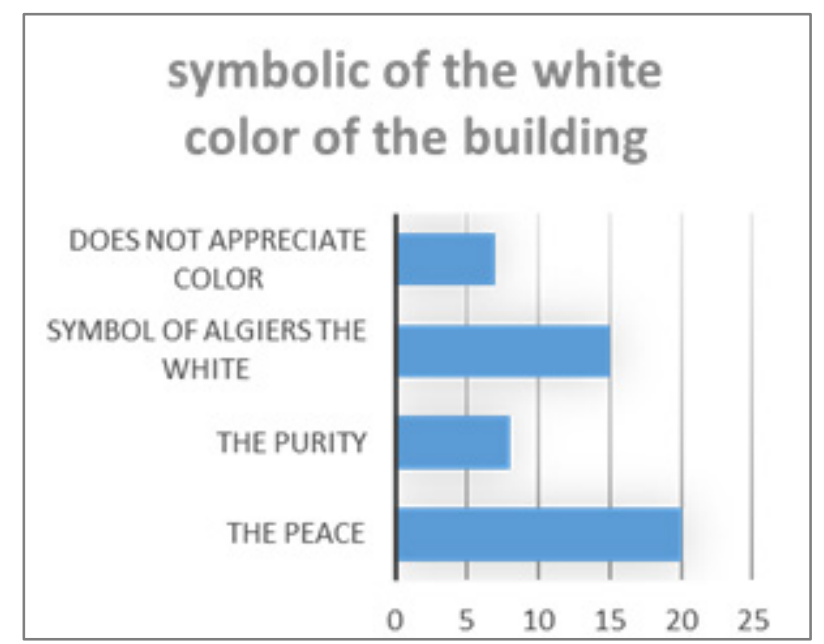

Figure 14. Diagram representing the symbolism of the color white for the questioned people (Source: Authors)

For the reading of the facade, $20 \%$ of the respondents found that the big post office has a grandiose and unbalanced facade, $80 \%$ of the respondents had a positive appreciation for the façade: $46 \%$ qualified it as beautiful and attractive, $20 \%$ as harmonious and balanced, and $14 \%$ as rich in decoration [Figure 15]. 


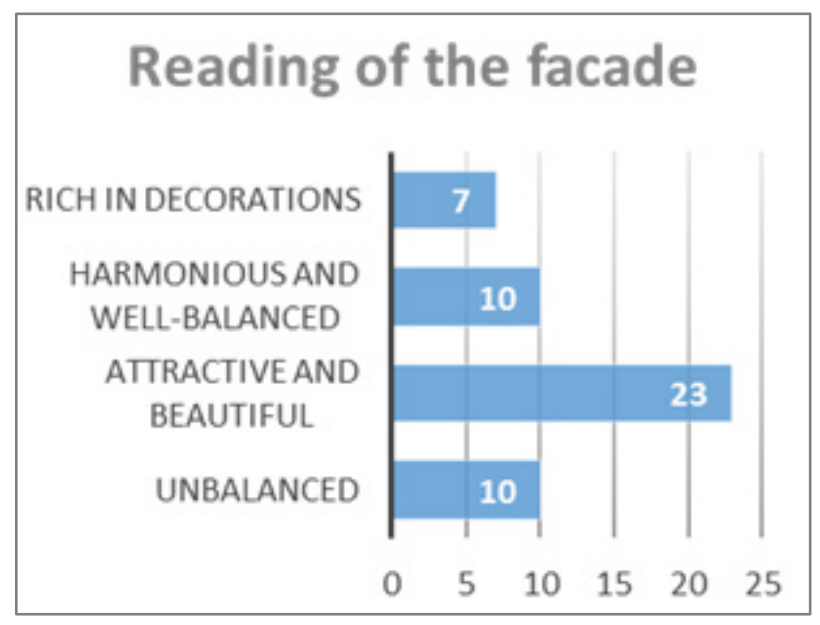

Figure 15. Diagram representing the reading of the facade of the big post office (Source: Authors)

To describe the architectural and decorative elements of the big post office of Algiers, a close distribution between those who chose Islamic culture as a representation of these elements $(26 \%)$ and those who opted for the architecture of mosques (30\%) as well as those who find in these elements a very sophisticated artistic work (24\%). A small part of the respondents does not appreciate the architectural and decorative elements. They see that it is too loaded and outdated $(10 \%)$ or prefer not to express themselves (10\%) [Figure 16].

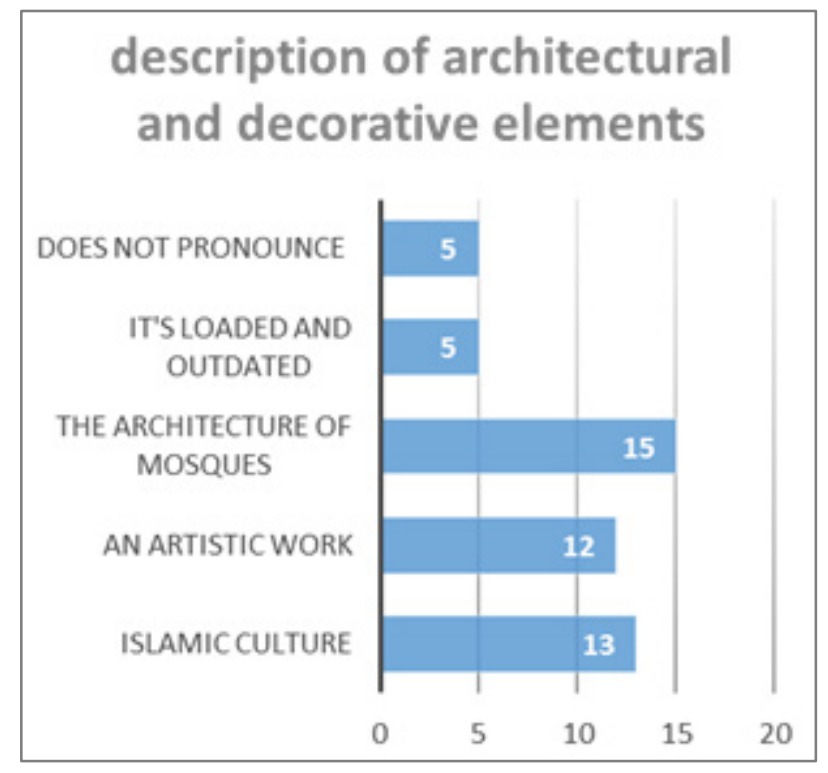

Figure 16. Diagram showing the description of the architectural and decorative elements of the big post office. (Source: Authors)

\subsection{Symbolic Evaluation of the Big Poste Office of Algiers}

For the question of the significance and the symbolism of the building for the respondents (who were all from the city of Algiers). $40 \%$ of the respondents find that the building symbolizes the Islamic art and architecture, an equal distribution of $26 \%$ between a part of the respondents, the big post office of whom symbolizes for them the city of Algiers, and those who have no comment on the subject. $8 \%$ of the respondents chose beauty and originality as a response to the symbolism of the big post office of Algiers [Figure 17].

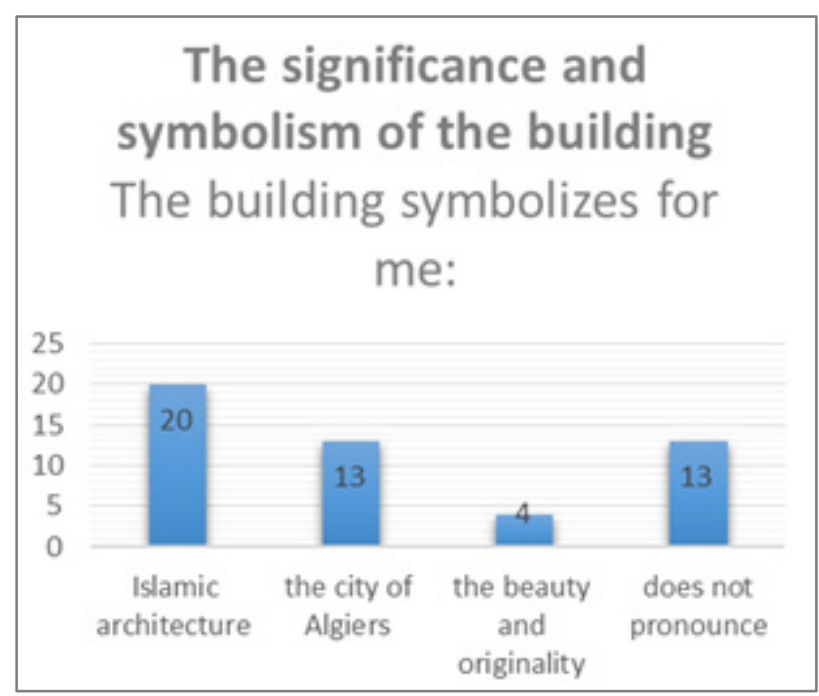

Figure 17. Diagram representing the meaning and symbolism of the big post office for the respondents, (Source: Authors)

For the memorial value of the building to the respondents, a close distribution between the answers $(16 \%, 20 \%, 20 \%)$, which oscillate between history, childhood and French colonization. $20 \%$ of the respondents find that the post office reminds them of the manifestations that generally took place in front of the building, and the animations of the festivals that were projected on its façade [Figure 18].

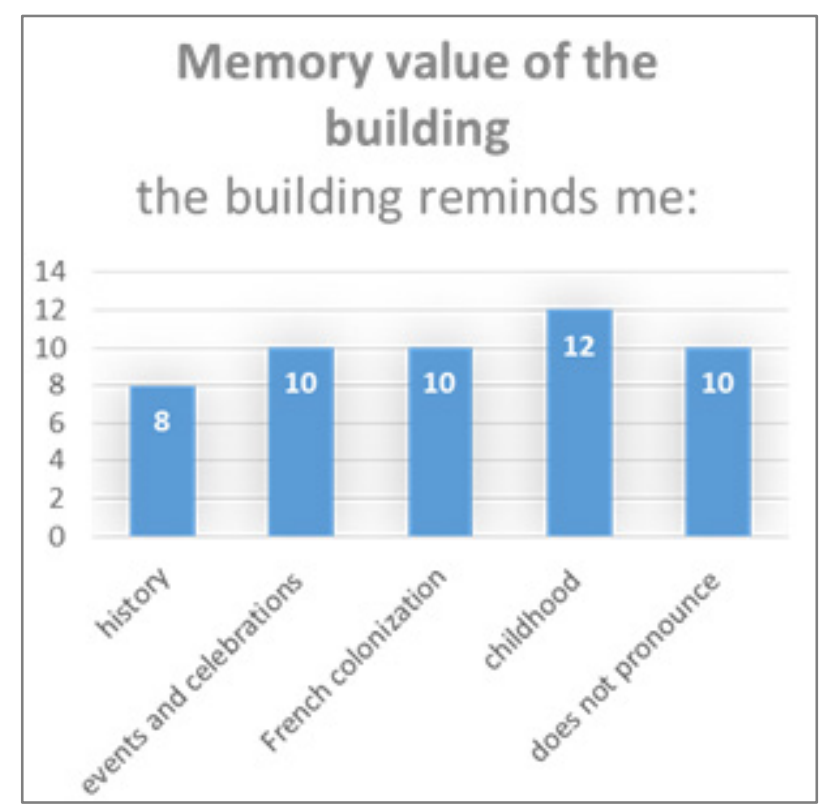

Figure18. Diagram representing the memory value of the big post office for respondents, (Source: Authors). 


\subsection{Urban Dimension of the Building}

For the importance of the big post office in the city of Algiers, the majority of the questioned $(96 \%)$ find the equipment very important; it marks for them the center of Algiers. [Figure 19].

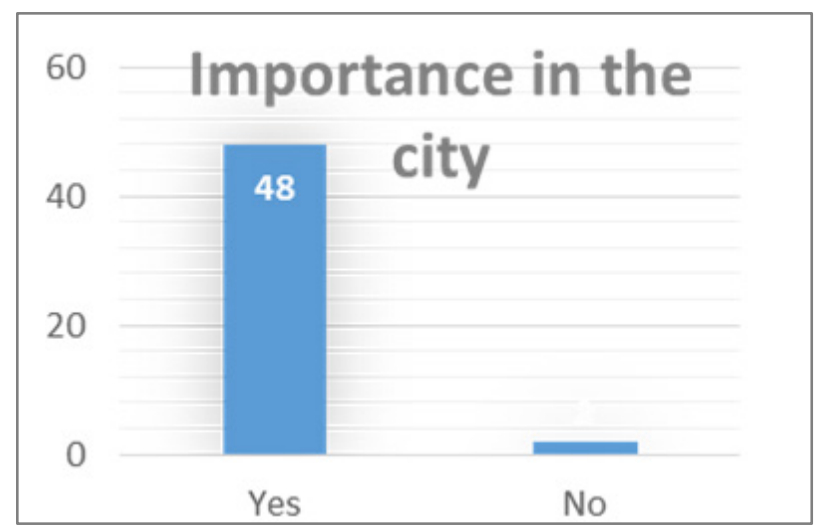

Figure 19. Diagram representing the importance of the big post office in the city of Algiers, (Source: Authors)

For its role in the urban space, $40 \%$ see it as an urban landmark, $27 \% \mathrm{f}$ see it as a meeting point and $15 \%$ see the post office as a structuring equipment of the city center. $18 \%$ of the respondents have no idea of this subject [Figure 20].

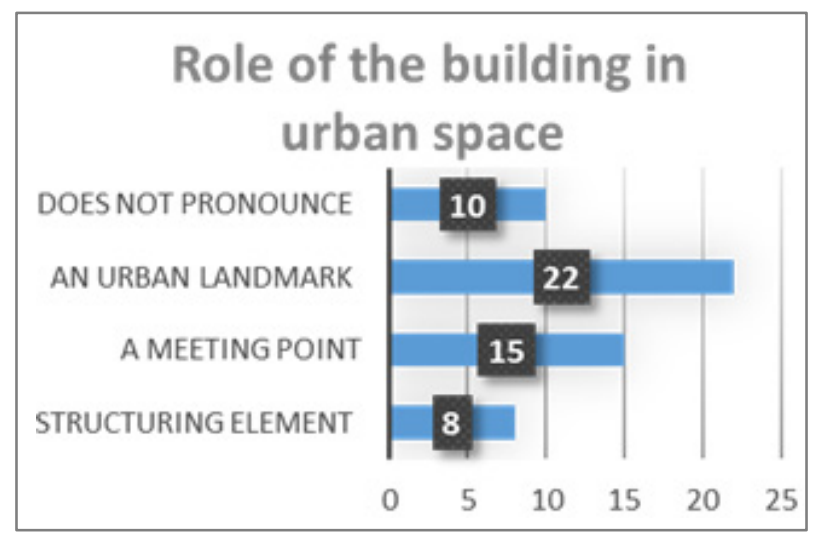

Figure 20. Diagram representing the role of the big post office in the urban space, (Source: Authors).

\subsection{Other (assets)}

To answer the question of identification in the architectural style of the building (whether respondents identify themselves or not in the architecture of the post office), $60 \%$ of the respondents do not identify themselves in the architecture of the building justifying this choice that it is a colonial legacy. $40 \%$ of the respondents responded positively judging that the post office in Algiers represents the Algerian culture and identity. [Figure 21].

\section{Identification in the architectural style of the building}

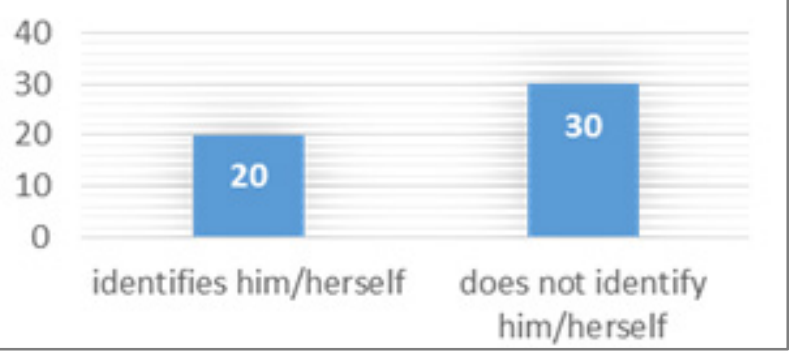

Figure 21. Diagram representing the identification of the respondents in the architectural style of the big post office, (Source: Authors)

In order to clarify the question of the patrimonialization of the building, the respondents answered at a percentage of $85 \%$ for the patrimonialization they see in the big post office a historical monument, which reflects the image of the city of Algiers. For them it can only be safeguarded, developed and considered as national heritage. $15 \%$ of the respondents answered negatively to the question of patrimonialization, arguing that any architectural production resulting from the period of French colonization should not have a patrimonial status [Figure 22].

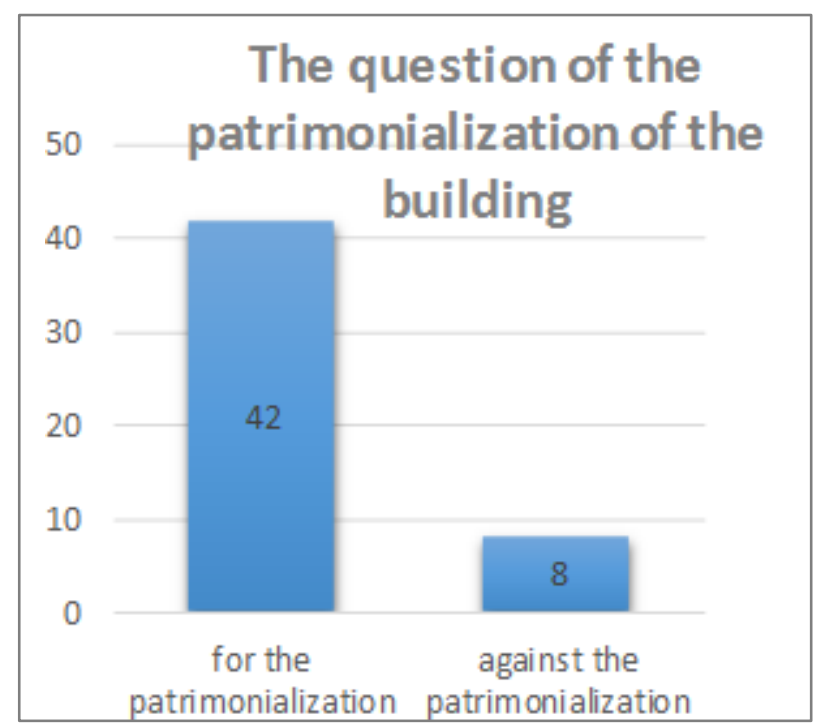

Figure 22. Diagram representing the answers of the respondents on the question of the patrimonialization of the big post office, (Source: Authors)

\section{Discussions}

The examination of the results of the survey carried out on the big post office of Algiers showed that:

The respondents appreciate well the architecture of the great post office of Algiers. They present certain 
knowledge of its period of edification. For the architectural style, we noticed confusion among them between Ottoman, Islamic and French style.

For the shape of the big post office, the question find that it is a shape which corresponds much more to a mosque than a post office, they find in its white color the peace and the purity, a color which symbolizes for them the city of Algiers. A positive appreciation was given to the facade judged attractive and balanced.

For the representation of architectural and decorative elements, the respondents find that these elements represent the architecture of mosques and reflect Islamic culture.

The symbolic evaluation of the great post office of Algiers reveals an attachment of the population to the building.

The big post office plays an important role in the urban space of the city center of Algiers, it represents for the Algerians an urban landmark and a favorite meeting point.

For the question of the identification in the architectural style of the great post office in Algiers, the majority of respondents see that the architecture of the great post office does not reflect their identity. They think that it is a colonial product. These negative answers on the identity question did not prevent that the majority of respondents were for the patrimonialization of the big post office, which they saw as an important historical monument.

\section{Conclusions}

We note a social acceptance and a willingness to preserve the built heritage of the French period; this acceptance is explained by a historical attachment and recognition of aesthetic, artistic and social values. Although the identity value is not the consensus of the respondents, they easily attribute heritage status to this architectural production. This led us to ask the question of the identity dimension of the architectural and urban heritage of the colonial period and the way we build a heritage without identifying with it.

Notwithstanding, this searches for images with ordinary and atypical social meanings. They reveal social and mental representations; showing the limits of predisposition of the respondents, in terms of simple material means, as well as the diversity of social groups and the disparity of points of view between generations.

This work allowed us to understand the meaning that the Algerian population shows an intention to the architectural heritage issued from the colonial period. This will finally give us the opportunity to inscribe this social representation to the logics of institutional patrimonialization.

\section{REFERENCES}

[1] Deluz. J. J, "The urbanism and architecture of Algeria, a critical overview". OPU: Mardaga, 1988, p.30

[2] Foura Y, Foura M, "The patrimonialization of neo-Moorish and Art Deco fabrics in Constantine: a strategy for sustainable preservation". International Symposium: Interventions on Existing Fabrics for a Sustainable City. Constantine, Algeria, May, 2011.

http://lautes.net/wp-content/uploads/2018/11/appel_colloq ue_2011.pdf,

https://fr.calameo.com/books/00089986924a0f7628685

[3] Beguin F, "Arabisances, Architectural decoration and urban design in North Africa 1830-1950". Paris: Dunod, 1983, p.14.

[4] Bougdah H., Djermouli A., "Urban Dwellings in Post-Colonial Algeria: From a housing crisis to a crisis of identity the case of Algeria". Proceedings of the Alternatives to the present Conference, Cleveland, 2018, https://www.researchgate.net/publication/332466250_Urba n_Dwellings_in_Post-Colonial_Algeria_From_a housing crisis_to_a_crisis_of_identity_The_case_of_Algeria

[5] The medersa: a Muslim religious educational institution

[6] The mihrab: Niche practiced in the wall of a mosque and oriented towards Mecca.

[7] PISI M. A.,"Landscape and architecture of a metropolis in Africa; Algiers, 1930 -1962", Doctoral thesis, under the direction of Jean-Louis Cohen and Daniele Vitale, University of Paris VIII. June 2006, 263 p.

[8] ARRIF A., "The paradox of the construction of the patrimonial fact in a colonial situation, the case of Morocco ", Muslim World and Mediterranean journal, vol.73, no.1, pp. 152-166, 1994, DOI: 10.3406/remmm.1994.1673.

[9] Benaidja I., "The ordinary relationship to the built heritage of the period of French colonization in Algeria: The example of the town hall of Kherrata (Bejaia)". L'année du Maghreb, vol. 19, pp. 81-98, 2018, DOI: 10.4000/anneemaghreb.4090.

[10] Sinou A, "Cultural and political stakes of the heritage development of colonial spaces", Autrepart, Vol.33, No.1, (no 33), pp 13-31, 2005, DOI: 10.3917/autr.033.0013

[11] Abric J.-C, "Experimental study of social representations", In Denis J, "Social representations", Paris: Presses universitaires de France, 2003, pp.203-233.

[12] Fayeton P, "The urban rhythm. Elements to intervene on the city”, Paris: L'Harmattan, 2000, p.67.

[13] Laudati, P, "Forms of architecture: languages, images and shared practices", In Lardellier P, "Shapes in the making, Technological, communicational and symbolic approaches", Hermes Science Publishing, 2014, p.189

[14] DE LA TORE M., MASSON R., "Introduction”. In DE LA TORE M, "Assessing the Values of Cultural Heritage, Research Report", The Getty Conservation Institute, Los Angeles,2002, pp. 3-4

[15] Navez-Bouchanine, F. (1996, 2010). "The medina in Morocco: elites and inhabitants, Projects for space in different times". The Annals of Urban Research, Paris, 
No.72, 1996, pp. 14-22.

[16] Vergès $P$, "The analysis of social representations by means of questionnaires". French journal of sociology, Vol.42, No.3, 2001, pp.537-561, DOI: 10.2307/3323032.

[17] Cyril I, "Ordinary patrimonializations. Essay of ethnographic images", "Ethnographies of heritage practices: temporalities, territories, communities", ethnographiques.o rg, No.24, July, 2012,

https://www.ethnographiques.org/2012/Isnart
[18] Laudati P. (2014). "Forms of architecture: languages, images and shared practices", In, Lardellier P, "Shapes in the making. Technological, communicational and symbolic approaches", Hermes Science Publishing, Collection Cognitive Science and Knowledge Management, 2014, p. 189, 978-1-78405-011-5. 〈halshs-01224063〉

[19] Griffin A., Hauser J.R., "The voice of the customer", Marketing Science, Vol.12, No.1, 1993, pp. 360-373. https://doi.org/10.1287/mksc.12.1.1 